\title{
SPORTIVE
}

https://dergipark.org.tr/tr/pub/sportive

\section{Erken Ergenlik Döneminde Öğrencilerin Beden Eğitimi ve Spor Dersine Katılmada Öğretmenden Beklentileri ile Okul Dirençlerinin İncelenmesi}

\author{
Eray ÖZÇELIKKĊ
}

Konya İl Milli Eğitim Müdürlüğü , Konya/Turkey

Orijinal Makale

Gönderi Tarihi:08.06.2021

Kabul Tarihi:30.08.2021

Bu çalışmanın amacı erken ergenlik döneminde öğrencilerin beden eğitimi ve spor dersine katılmada öğretmenden beklentileri ile okul dirençlerinin incelenmesidir. Çalışma 708 kız ve 592 erkek olmak üzere toplam 1300 ortaokul öğrencisi üzerinde yürütülmüştür. Çalışmaya katılan öğrencilerin; 453'ü 11 yaş (\%34,8), 352'si 12 yaş (\%27,1), 342'si 13 yaş (\%26,3) ve 153 'ü 14 yaşındadır $(\% 11,8)$. Bu öğrencilerin 350'si $(\% 26,9)$ beşinci sınıf öğrencisi, 345’i (\%26,5) altıncı sınıf öğrencisi, 306’sı $(\% 23,5)$ yedinci sınıf öğrencisi ve 299 ’u (\%23,1) sekizinci sınıf öğrencilerinden oluşmuştur. Veri toplama aracı olarak, Beden Eğitimi ve Spor Dersine Katılmada Öğretmenden Beklentileri ve Okul Direnci ölçekleri kullanılmıştır. Verilerin analizinde, cinsiyet farklılıklarını tespit etmek için bağımsız t-testi, sınıf ve yaş farklılıklarını tespit etmek için ise tek yönlü varyans analizi (Anova) kullanılmıştır. Post hoc için scheffe testi uygulanmıştır. Analiz sonucunda kızlar ve erkekler arasında beden eğitimi ve spor dersine katılmada öğretmenden beklentileri değerlerinin erkekler lehine istatiksel açıdan anlamlı düzeyde farklı olduğu tespit edilmiştir. Okul dirençleri analizi sonuçlarında ise yaş ve sınıf düzeylerinin istatiksel açıdan farklı olduğu tespit edilmiştir. Sonuç olarak erken ergenlik döneminde, derse katılmada öğretmenden beklentilerinin cinsiyete bağlı olarak değişmesi ergenliğin getirmiş olduğu bu kritik dönemde cinsiyet özelliklerinin dikkate alınması gerektiği sonucuna varılmıştır. Ayrıca yaş ve sınıf düzeylerinin artması ile okul direnci arasında pozitif korelasyon olması, öğrencilerin erken ergenliğin sonlarına doğru beklenti ve isteklere uyum sağladığı sonucunu ortaya çıkarmıştır.

Anahtar Kelimeler: Okul, Ögrenci, Beklenti, Tutum

\section{Examination of the Expectations of Students from Teachers and School Resistance in Participating in Physical Education and Sports Lessons in Early Adolescence Period}

The main purpose of this study is to examine the expectations of students from teachers and school resistance in participating in physical education and sports lessons in early adolescence. The study was carried out on a total of 1300 middle school students including 708 girls and 592 boys. The students participating in the study; 453 were 11 years old (34.8\%), 352 were 12 years old (27.1\%), 342 were 13 years old (26.3\%), 153 were 14 years old (11.8\%), and in these age groups, $345(26.5 \%)$ were $6^{\text {th }}$ grade students, $306(23.5 \%)$ were $7^{\text {th }}$ grade students and $299(23.1 \%)$ were $8^{\text {th }}$ grade students. "Expectations from the Teacher in Participating Physical Education Lessons" and "School Resistance" 
scales were utilized as data collection tools. Independent T-Test was used to determine gender differences and the one-way analysis of variance (ANOVA) was used to determine to detect grade and age differences. Scheffe test was used for post hoc. As a result of the tests, it was determined that the values of expectations from the teacher in participating in physical education lessons were statistically significant different between girls and boys. According to the results of the school resistance analysis, it was determined that the age and grade levels were statistically different. As a result, it was concluded that gender characteristics should be taken into account in this critical period brought about by the change of expectations from the teacher in participating in the lesson depending on gender in the early adolescence period. In addition, the positive increase in the correlation between the increase in age and grade levels and school resistance demonstrated that students adapted to expectations and wishes towards the end of early adolescence.

Keywords: School, Student, Expectation, Attitude

\section{GİRIŞ}

Çocukluktan yetişkinliğe geçisin ilk evresi, fiziksel büyümenin en hızlı olduğu, duygusal, sosyal ve zihinsel süreçlerdeki ani değişimlerle bireyin kendisi ve çevresi ile başa çıkma çabalarının yaşandığı bir dönem olarak karşımıza çıkan erken ergenlik dönemi, bireyin hayatındaki kritik dönemlerin başlangıcıdır. Son yıllarda erken ergenliğin etkileri üzerine yapılan çalışmalar bu kritik dönemin önemini de ortaya çıkartmaktadır (Erkek vd., 2021; Uzun vd., 2020).

Erken ergenlik döneminde ergen bireyler bazı beklentiler içerisinde girer. Beklentiler ergen bireyin; ailevi, eğitim, sosyal çevreye uyum, kişiler arası çatışma gibi birçok alanda karşısına çıkabilir(Özbay et al., 2011). Ergenliğin getirdiği bu beklenti ve isteklere, uyum sağlayamayan ergenler hayatlarında farklı problemlerle karşı karşıya kalabilir. Bireyin eğitim hayatında da ortaya çıkabilecek bu problem durumlarına karşı, başarılı ve motive olmalarını etkileyecek birçok faktör vardır(Çelikkaleli, 2015). Bu faktörlerin başında da şüphesiz öğretim kurumları gelmektedir. Öğretim kurumlarında uygulanan beden eğitimi ve spor dersleri de öğrencilerin başarılı ve derse motive olmalarını sağlayabileceği içerikte olmalıdır (Sunay \& Sunay, 1996). Bireyler içinde bulundukları duruma karşı olumlu bir tutuma sahipse, ona yaklaşacak ve motive olacaktır. Ĕger olumsuz bir tavır sergilerse, ondan uzaklaşacak ve isteksiz davranacaktır. $\mathrm{Bu}$ nedenle beklenti ve tutumlar ile ilgili yapılacak çalı̧̧malar beden eğitimi ve spor dersi öğretmenleri açısından da önemli bulgular sağlayabilir(Şişko \& Demirhan, 2002).

Son yıllarda okula bağlılık kavramı öğrencilerin akademik başarıları ile ilişkilendirilmiştir. Öğrencilerin okula bağlllık düzeyleri; okulla ilgili olumlu duyguları, okul içi ve okul dışı etkinliklere katılma isteklerinin toplamı olarak ifade edilmektedir. (Akt. Kırbaç,2019, Fredricks, Blumenfeld ve Paris, 2004; Finn ve Voelkl, 1993; Robinson, 2016). Literatürdeki bir tanıma göre okul bağlılı̆̆ı; "Öğrenciler kendilerini okula ait hissetmeleri ve okulun amaçlarını benimsemeleri olarak ifade edildimiştir (Kalaycı \& Özdemir, 2013). 
Okul direnci kavramı ise, eğitim sistemindeki yaygın sorunlardan biridir. Sınıf Düzeni bozan, öğretmenlerin otoritesini zedeleyen, öğretimi engelleyen bu tür davranışlar, eğitim hedeflerine ulaşılmasını ve okulun işlevlerini engeller(Kırbaç, 2019). Birçok bilim adamının farklı direnç tanımları vardır. Örneğin Giroux (1983) okul direncini "öğrencilerin eğitim faaliyetlerine direnme olasılı̆̆g" olarak tanımlamaktadır. Bir başka tanımda; McLaren (1985) "okul kültürünün öğretimde meşruiyetine, gücüne ve uygunluğuna öğrencinin direniş davranışı” olarak tanımlar (Akt:Yüksel, 2003). Yapılanların tanımlara bakıldığında; okul direnci, öğrencinin okuldaki faaliyetleri, kendi zihniyetlerine, yaşam tarzlarına, ilgi alanlarına ve beklentilerine uymayan durumlara tepki davranışı gösterdikleri görülmüş̧ür. Tepki gösterdikleri durumlarda bir değişme olmadığını gördüklerinde ise bu tepkilerini direnç davranışına dönüştürdükleri görülmektedir. Bu davranış bazen sözlü veya fiziksel davranışları içerirken, bazen tepkisizlik olarak kendini gösterebilmektedir(Kırbaç, 2019).

Yıldıran ve diğerleri (1996) tarafından öğrencilerin ve spor dersine katılım beklentileri üzerine yapılan araştırma, kız öğrencilerin beden eğitimi ve spor ile ilgili beklentilerinin sosyal, psikolojik, ahlaki ve estetik konulara odaklanmasına rağmen, erkek öğrencilerin beklentilerinde fiziksel gelişim ön plana çıkmıştır. Yine bu alanda Sunay \& Sunay (1996) tarafından yapılan benzer bir çalışmada, sınıf düzeyleri ile beden eğitimi ve spor dersine katılma arasında anlamlı bir farkın olduğu tespit edilmiştir.

Öğrencileri motive eden ve derste başarılarını sağlayan bir diğer unsur ise öğretmenlerdir. Öğretmenler öğrencilerin istek ve beklentilerine cevap vererek onları desteklerse, onların aidiyet duygularını karşılayacaktır(Eryılmaz, 2013). Bunun sonucunda da öğrenciler okul ve öğretmenlere yönelik olumlu tutum ve davranışlarını da artıracaktır (Mouton et al., 1996). Okula ve öğretmene karşı olumlu tutuma sahip olan öğrenciler, bu şartlar altında okula, sınıfa gitmeye ve ödevlerini tamamlamaya istekli olacaklardır. Tersi durumda ise öğrenciler eğitim hayatlarını yarıda bırakabilecek veya sınıf tekrarı yapmak zorunda kalabileceklerdir (Eryılmaz, 2013).

Öğrenciler bazı öğretmenlerin derslerine yüksek katılım sağlarken, bazılarının derslerine katılımları daha az olur (Eryllmaz, 2013). Öğrencilere geri bildirim veren, bire bir yardım sunan ve okuldan sonrada öğrencilerin hayatları ile ilgilenen öğretmenlerin derslerine katılım daha fazla olmuştur (Phelan et al., 1992). Montalvo (1997) tarafından yapılan bir başka çalışmada öğrencilerin istedikleri öğretmenin özelleri sorulmuştur. Çalışmanın çıkan sonuçları arasında; olumlu dönütler sunan, kendileri ile ilgilenen, olumsuz durumları olumluya çeviren, öğrencilere saygı duyan, öğrencilere güvenen ve onların özgüvenini yükseltebilen ve çok fazla ödev ve görev vermeyen öğretmen özellikleri yer almıştır (Montalvo, 1997).

Bu bağlamda öğrencilerin, sınıf içerisinde öğretmen tarafından konulan kuralları eleştirememesi, etkinlik seçme konusunda ve etkinliğin uygulama sürecinde görüş bildirememesi, verilen ödevlerin yapılmaması, sevmediği öğretmenin dersine 
katılmak zorunda olması, derse gereken ilgi ve alakayı göstermemesi, derse geç gelmesi gibi davranışlar okul direnci davranışları olarak sayılabilir. Sınıftaki bu direnç davranışlar da sınıf atmosferinin bozulduğunu gösterebilir (Chan ve Tracy, 1996 ).

Modern dünyada artık öğrenciler; karar verebilen, sorgulayan ve araştıran, öğrendiklerini yaşamına aktarabilen bireyler olarak karşımıza çıkmaktadır. Öğrenciler içerisinde bulundukları gelişim dönemlerinde, öğretmenlerinden farklı istek ve beklentiler içerisinde olabilir. Bu istek ve beklentilerinin karşılanması durumu öğrencilerin okul, aile ve çevre hayatını etkileyecektir(Çelikkaleli, 2015). Bu bağlamda çalışmanın amacı da; erken ergenlik döneminde olan bireylerin beden eğitimi ve spor dersine katılmada öğretmenden beklentileri ile okul dirençleri durumlarının incelenmesi üzerine olmuştur. $\mathrm{Bu}$ amaç doğrultusunda aşağıdaki sorulara cevap aranmıştır.

1. Öğrencilerin beden eğitimi ve spor dersine katılmada öğretmenden beklentilerine cinsiyetin, yaşın ve sınıf düzeyinin etkisi var mıdır?

2. Öğrencilerin okul direncine cinsiyetin, yaşın ve sınıf düzeyinin etkisi var mıdır?

3. Öğrencilerin beden eğitimi ve spor dersine katılmada öğretmenden beklentileri ve okul dirençleri arasında korelasyon var mıdır?

\section{YÖNTEM}

\section{1.Çalışma Grubu}

Çalı̧̧manın verileri uygun örnekleme modeli ile belirlenmiş 2020-2021 eğitim öğretim yllında ortaokul düzeyinde öğrenim görmekte olan $708 \mathrm{kız}$ ve 592 erkek olmak üzere toplam 1300 öğrenci üzerinde yürütülmüştür. Çalışma 708 kız ve 592 erkek olmak üzere toplam 1300 ortaokul öğrencisi üzerinde yürütülmüştür. Çalışmaya katılan öğrencilerin; 453'ü 11 yaş (\%34,8), 352'si 12 yaş (\%27,1), 342'si 13 yaş (\%26,3) ve 153'ü 14 yaşındadır $(\% 11,8)$. Bu öğrencilerin 350'si $(\% 26,9)$ beşinci sınıf öğrencisi, 345’i $(\% 26,5)$ altıncı sınıf öğrencisi, 306’sı $(\% 23,5)$ yedinci sınıf öğrencisi ve 299’u (\%23,1) sekizinci sınıf öğrencilerinden oluşmuştur.

\subsection{Araştırma Yayın Etiği}

Araştırma için, bir devlet üniversitesi kararı ile etik uygunluk onayı alınmıştır.

\subsection{Veri Toplama Araçları}

Veri toplama aracının ilk bölümünde, öğrenci demografik bilgileri, ikinci ölümünde ise Beden Eğitimi Dersine Katılmada Öğretmenden Beklentileri ve Okul Direnci ölçekleri yer almıştır. Öğrencilerin öğretmenden beklentilerini ölçmek için Eryılmaz (2013) tarafından geliştirilen 'Derse Katılmada Öğretmen Beklentileri Ölçeği' kullanılmıştır. Ölçek 3 faktör 15 maddeden oluşmakta ve 1-4 arası derecelendirilmiş 4'lü Likert tipi 
bir ölçektir (Tamamen Katılıyorum-4, Katılıyorum-3, Katılmıyorum-2, Kesinlikle Katılmıyorum-1). Öğrencilerin okul dirençlerini ölçmek için Kırbaç(2019) tarafından geliştirilen 'Okul Direnci Ölçeği' kullanılmıştır. Ölçek 15 maddeden oluşmakta ve 1-5 arası derecelendirilmiş 5'li Likert tipi bir ölçektir (Tamamen Katılıyorum-5, Çoğunlukla Katılıyorum-4, Orta Düzeyde Katılıyorum-3, Az Katılıyorum-2, Hiç Katılmıyorum-1). Google Forms üzerinden hazırlanan Çevirim içi olarak öğrencilere iletilen çalışmanın güvenirliğini sağlamak için ise öğretmenler ile iletişime geçilerek sadece anketin uygulanacağı zaman dilimlerinde anketin açık kalması sağlanmıştır. Ölçeklerin uygulanma süresi 10-15 dakika arasındadır. Yönerge ise öğrencilere ölçeği uygulayacak öğretmenler tarafından yazılı olarak aktarılmıştır.

\subsection{Verilerin Analizi}

$\mathrm{Bu}$ çalışmada, veri analizinde hem tanımlayıcı hem de çıkarımsal istatistik analizi kullanılmıştır. Veri analizi için SPSS 26 programı kullanılmıştır. Değişkenlerin ortalama ve standart sapmalarını tespit etmek için tanımlayıcı istatiksel yöntem kullanılmıştır. Diğer değişkenleri analiz etmek için ise çıkarımsal istatiksel yöntemden yararlanılmıştır. Cinsiyet farklılıklarını tespit etmek için bağımsız t-testi sınıf ve yaş farklılıklarını tespit etmek için tek yönlü varyans analizi (ANOVA) kullanılmıştır. Post hoc için scheffe testine bakılmıştır. Tek yönlü varyans analizi ve bağımsız t-testinin varsayımları, bağımsız gözlem, normallik kontrolü ve varyans homojenliğidir. Tüm gözlemler bağımsız olarak yapılmıştır. Normallik kontrolü için, Skewness ve Kurtosis değerlerine bakılmış ve sonuçların +1 ile -1 arasında olduğu yani normal bir şekilde dağılım olduğu gözlemlenmiştir(Groeneveld \& Meeden, 1984). Varyans homojenliği için Levene testi kullanılmıştır. Öğrencilerin öğretmenden beklentileri ile okul dirençleri arasındaki ilişkiyi analiz etmek için Pearson korelasyon katsayısı kullanılmıştır. Anlamlılık düzeyi 0.05 olarak kabul edilmiştir.

\section{BULGULAR}

Bu bölümde öğrencilerin demografik bilgilerinin yanı sıra öğrencilerin beden eğitimi ve spor dersi öğretmeninden beklentileri ile okul dirençleri arasındaki ilişkisi analiz edilip, ayrıca bu değişkenlerin cinsiyet, yaş ve sınıf farklılıklarına bakılmıştır 
Araştırma Sorusu 1: Öğrencilerin beden eğitimi ve spor dersine katılmada öğretmenden beklentilerine cinsiyetin, yaşın ve sınıf düzeyinin etkisi var mıdır?

Cinsiyetin beden eğitimi ve spor dersine katılmada öğretmeninden beklentilerine etkisini ölçmek için sorulan sorulara verilen cevaplar, bağımsız t-test sonuçlarına göre analiz edilmiştir. Erkekler $(X=3.54, S S=.29)$ ile kızlar arasında $(X=3.57, S S=.27)$ Beden Eğitimi ve Spor dersi öğretmen beklentileri açısından anlamlı fark bulunmuştur; t $(2.108)=\mathrm{df}(1224,03), \mathrm{p}<0.05, \mathrm{r}^{2}=0.79$.

Tablo 1.

Katılımcıların Demografik Özellikleri

\begin{tabular}{lcc}
\hline Cinsiyet & $\boldsymbol{N}$ & $\%$ \\
\hline Erkek & 592 & 45.5 \\
Kız & 708 & 54.5 \\
\hline Yaş & & \\
\hline 11 yaş & 453 & 34.8 \\
12 yaş & 352 & 27.1 \\
13 yaş & 342 & 26.3 \\
14 yaş & 153 & 11.8 \\
\hline Sınıf & & \\
\hline 5.sınıf & 350 & 26.9 \\
6.sinıf & 345 & 26.5 \\
7.sınıf & 306 & 23.5 \\
8.sinıf & 299 & 23.1 \\
\hline Toplam & $\mathbf{1 3 0 0}$ & $\mathbf{1 0 0}$ \\
\hline
\end{tabular}

\section{Tablo 2.}

Beden eğitimi ve spor dersine katılmada öğretmen beklentilerinin yaşlara göre ilişkisi (ANOVA)

\begin{tabular}{llccccc}
\hline & & $\boldsymbol{s s}$ & $\boldsymbol{s d}$ & $\boldsymbol{m s}$ & $\boldsymbol{f}$ & $\boldsymbol{p}^{*}$ \\
\hline Okul & Gruplar Arası & .204 & 3 & .068 & .853 & .465 \\
dirençleri & Gruplar içi & 103.347 & 1296 & .080 & & \\
& Toplam & 103.551 & 1299 & & & \\
\hline
\end{tabular}

*p $<0.05$

Beden eğitimi ve spor dersine katılmada öğretmen beklentilerinin yaşlara göre ilişkisi tek yönlü varyans analizi ile incelenmiştir. Tek yönlü varyans analiz sonuçlarına göre yaşlar arasında istatistiksel olarak anlamlı bir fark bulunmamıştır $\mathrm{F}(3,1296)=.853, \mathrm{p}=.465$. (Tablo 2.) 


\section{Tablo 3.}

Beden eğitimi ve spor dersine katılmada öğretmen beklentilerinin sınıf düzeylerine göre ilişkisi (ANOVA)

\begin{tabular}{llccccc}
\hline & & $\boldsymbol{s s}$ & $\boldsymbol{s d}$ & $\boldsymbol{m s}$ & $\boldsymbol{f}$ & $\boldsymbol{p}^{*}$ \\
\hline Öğretmen & Gruplar Arası & .42 & 3 & .139 & 1.742 & .157 \\
beklentileri & Gruplar içi & 103.135 & 1296 & .080 & & \\
& Toplam & 103.551 & 1299 & & & \\
\hline
\end{tabular}

${ }^{*} \mathrm{p}<0.05$

Beden eğitimi ve spor dersine katılmada öğretmen beklentilerinin sinıf düzeylerine göre ilişkisi tek yönlü varyans analizi ile incelenmiştir.. Tek yönlü varyans analizine göre sınıflar arasında istatistiksel olarak anlamlı bir fark bulunmamıştır F $(3,1296)$ $=1.742, \mathrm{p}=0.157$ (Tablo 3).

Araştırma Sorusu 2: Öğrencilerin okul direncine cinsiyetin, yaşın ve sınıf düzeyinin etkisi var midır?

Cinsiyetin okul direncine etkisini ölçmek için sorulan sorulara verilen cevaplar, bağımsız t-test sonuçlarına göre analiz edilmiştir T-test sonuçlarına göre, erkekler ( $X$ $=2.51, S S=1.17)$ ile kızlar arasında $(X=2.44, S S=1.18)$ okul dirençleri açısından anlamlı bir fark bulunmamıştır t (1.097) $=$ df (1298), $\mathrm{p}>0.05$.

\section{Tablo 4.}

Okul direncinin yaşlara göre ilişkisi (ANOVA)

\begin{tabular}{llccccc}
\hline & & $\boldsymbol{s s}$ & $\boldsymbol{s d}$ & $\boldsymbol{m s}$ & $\boldsymbol{f}$ & $\boldsymbol{p}^{*}$ \\
\hline Okul & Gruplar Arası & 43.473 & 3 & 14.491 & 10.753 & .000 \\
dirençleri & Gruplar içi & 1749.490 & 1296 & 1.350 & & \\
& Toplam & 1792.964 & 1299 & & & \\
\hline
\end{tabular}

$* \mathrm{p}<0.05$

Okul dirençlerinin yaşlara göre ilişkisi tek yönlü varyans analizi ile incelenmiştir. Tek yönlü varyans analiz sonuçlarına göre yaşlar arasında istatistiksel olarak anlamlı bir fark vardır $\mathrm{F}(3,1296)=10.753, \mathrm{p}=.000$ (Tablo 4). Anlamlı farkın hangi gruplar arasında olduğunu saptamak için Scheffe post-hoc testi yapılmıştır. Bu testin sonuçlarına göre, 14 yaş $(X=2.69, S S=1.09)$ ile 11 yaş arasında $(X=2.26, S S=1.17)$ ve 13 yaş $(X=2.69, S S=1.18)$ ile 11 yaş arasında $(X=2.26, S S=1.17)$ arasında istatistiksel olarak anlamlı bir fark bulunmuştur. Diğer yaşlar arasında istatistiksel olarak anlamlı bir fark bulunamamıştır. 
Özçelikci E., Erken Ergenlik Döneminde Öğrencilerin Beden Eğitimi ve Spor Dersine Katılmada

Öğretmenden Beklentileri ile Okul Dirençlerinin İncelenmesi.SPORTIVE, 4(2), 77-87

Tablo 5.

Okul direncinin sınıf düzeylerine göre ilişkisi (ANOVA)

\begin{tabular}{llccccc}
\hline & & $\boldsymbol{s s}$ & $\boldsymbol{s d}$ & $\boldsymbol{m s}$ & $\boldsymbol{f}$ & $\boldsymbol{p}^{*}$ \\
\hline Okul & Gruplar Arası & 26.310 & 3 & 8.770 & 6.434 & .000 \\
dirençleri & Gruplar içi & 1766.654 & 1296 & 1.363 & & \\
& Toplam & 1792.964 & 1299 & & & \\
\hline
\end{tabular}

$* \mathrm{p}<0.05$

Okul dirençlerinin sınıf düzeylerine göre ilişkisi tek yönlü varyans analizi ile incelenmiştir. Tek yönlü varyans analizine göre sınıflar arasında istatistiksel olarak anlamlı bir fark bulunmuştur F $(3,1296)=6.434, \mathrm{p}=0.00$ (Tablo 5). Anlamlı bir fark bulunduğu için Scheffe post-hoc testi yapılmıştır. Bu testin sonuçlarına göre, beşinci sinıf ile $\left(X^{-}=2.27, S S=1.17\right)$ yedinci $\operatorname{sinif}\left(X^{-}=2.54, S S=1.17\right)$ arasında ve beşinci sinıf ile $(X=2.27, S S=1.17)$ sekizinci $\sin 1 f(X=2.65, S S=1.15)$ arasinda istatistiksel olarak anlamlı bir fark bulunmuştur.

Araştırma Sorusu 3: Öğrencilerin beden eğitimi ve spor dersine katılmada öğretmenden beklentileri ve okul dirençleri arasında korelasyon var mıdır?

Yapılan Pearson korelasyon analizi sonuçlarına göre öğrencilerin beden eğitimi de spor dersine katılmada öğretmenden beklentileri ile okul dirençleri arasında bir ilişkiye rastlanmamıştır $(r=.023, \mathrm{p}>.405)$.

\section{TARTIŞMA ve SONUÇ}

$\mathrm{Bu}$ araştırmada, erken ergenlik dönemindeki öğrencilerin beden eğitimi ve spor dersine katılmada öğretmenden beklentileri ile okul dirençleri arasındaki ilişki durumu incelenmiş ve bu ilişkinin cinsiyet, yaş ve sinıf düzeyi değişkenlerine göre nasıl farklılaştığı ortaya konulmuştur.

Araştırmada, cinsiyetin öğrencilerin beden eğitimi ve spor dersine katılmada öğretmenden beklentilerine etkisi incelendiğinde anlamlı bir ilişkisi bulunmuştur. Kız öğrencilerin erkek öğrencilere göre derse katılmada öğretmenden beklentilerinin daha fazla olduğu görülmüştür. Literatür incelendiğinde farklı yaş grupları için yapılan çalışmalarda da aynı sonuçlar ortaya konulmuştur. 990 ortaöğretim öğrencisi üzerinde yapılan öğrencilerin beden eğitimi dersi ve ders dışı etkinliklerine yönelik tutumlarına ilişkin çalışmada, erkek ve kız öğrenciler arasında istatiksel açıdan fark bulunmuştur(Ayberk et al., 2011). Diğer bir çalışma üniversite öğrencilerinin öğretmen beklentisi yönelik çalışmada da kız ve erkek öğrenciler arasında anlamlı bir ilişki ortaya konulmuştur (Ergin \& Karataş, 2018). Bu sonuçlar, öğretmen beklentilerinde cinsiyetin sadece erken ergenlik döneminde değil, farklı yaş gruplarında da öğretmenden beklentilerin farklılaşabildiğini göstermektedir. $\mathrm{Bu}$ beklenti farklılıklarının sebepleri, öğrencilerin eğitim-öğretim seviyeleri ve okul 
türlerinden kaynaklandığı düşünülmektedir.

Öğrencilerin beden eğitimi ve spor dersine katılmada öğretmenden beklentilerine yaşların ve sınıf düzeylerinin etkisi incelendiğinde anlamlı bir fark bulunmamıştır. Fakat farklı dersler için yapılan çalışmalarda sınıf düzeyleri açısından anlamlı fark olduğu ortaya konulmuştur. Sosyal bilgiler dersi için öğrencilerin öğretmenden beklentilerinin 6.sınıf öğrencilerinin 7.ve 8.sınıf öğrencilerine göre anlamlı farklılıkları bulunmuştur(Çelikkaya, 2008). Öğrencilerin Türkçe dersi öğretmeninden beklentilerinin sinıf düzeylerine etkisi incelendiğin de yine sinıf düzeyleri arasında anlamlı fark bulunmuştur(Bağcı \& Temizkan, 2006).8.sınıf öğrencilerinin öğretmenden beklentilerinin 5-6 ve 7.sınıf öğrencilerine göre daha yüksek olduğu ortaya konulmuştur. Sonuçlara bakıldığında öğrencilerin farklı derslerde sınıf düzeyleri açısında öğretmen beklentilerinin değişebildiği görülmektedir. Ayrıca sınıf ve yaş büyüdükçe öğretmen beklentilerinin de yükseldiği gözükmektedir. Bu durum uygulamalı dersler ile teorik dersler için beklentilerin değişebileceğini gösterebilir.

Çalışmanın bir diğer sonucunda ise okul direncine cinsiyet etkisine bakıldığında kızlar ve erkekler arasında istatiksel açıdan fark bulunmamıştır. Literatürde yapılan çalışmalar incelendiğinde okul direncine yönelik çalışmaların kısıtlı olduğu görülmektedir. (Kırbaç, 2019)' a göre yapılan çalışmalar genellikle akademik başarı ile okul direnci ilişkisi ya da öğretmenin sınıf içerisinde göstermiş olduğu davranışların okul direncine olan etkisi incelenmiştir.

Okul direncine öğrenci yaşlarının etkisi incelendiğinde, istatiksel olarak anlamlı olduğu görülmüştür. Bulgular 14 yaş ile 11 yaş arasında ve 13 yaş ile 11 yaş arasında anlamlılık olduğunu ortaya çıkarmıştır.14 yaş ve 13 yaşın okul dirençlerinin 11 yaş öğrenci grubuna göre daha yüksek olduğu görülmektedir. Literatürdeki çalışmalarda bu sonuçları desteklemektedir. 22 maddeden oluşan ve 199 öğrenciye uygulanan çalışmada, 7.sınıf öğrencilerinin diğer sınıf düzeylerine göre daha fazla okula karşı direnç gösterip motive oldukları ortaya konulmuştur. Fakat diğer sınıf düzeylerine de okula karşı dirençlerinin artırılması için özel ilgi gösterilmesi gerektiğini belirtmiştir(Yeung \& McInerney, 2005). Diğer bir çalışmada öğretmenin sınıf yönetiminde planlı ve programlı olması, öğrencinin beklenti ve isteklerinin karşlanması durumlarının sonucu olarak öğrencinin derse ve okula olan motivasyonun artacağını belirtmiştir(Vatansever Bayraktar, 2015).

Çalı̧̧manın diğer bir diğer sonucunda ise sınıf düzeylerinin okul direncine etkisine bakıldığında yaş gruplarında olduğu gibi sınıf düzeyleri arasında da istatiksel anlamlı fark bulunmuştur. Sekizinci sınıf ile beşinci sınıf ve yedinci sınıf ile beşinci sınıf arasında istatiksel olarak anlamlı bir fark bulunmuştur. Literatürdeki çalışmalarda bunu desteklemektedir. Alanyazın taramasında da sınıf düzeyleri ile okul dirençleri arasında anlamlı bir ilişki olduğunu ortaya konulmuştur. (Kılıç \& Çimen, 2018; Sunay \& Sunay, 1996). Sonuç olarak; yaş ve sınıf düzeylerinin okul dirençlerine etkisinin 
istatiksel açıdan anlamlı olmass, bu durumu bireyin ergenlik döneminin içinde olduğu süreç boyunca okul, öğretmen, arkadaş ve ailenin, bireyin okula karşı direnç göstermesi konusunda önemli rol aldıkları söyleyebilir.

Diğer bir sonuç ise ortaokul öğrencilerinin beden eğitimi ve spor dersine katılmada öğretmenden beklentiler ile okul dirençleri arasında anlamlı bir korelasyon bulunamamıştır. Fakat literatürde yapılan çalışmalar farklı sonuçlar göstermiştir. Örneğin, ergenler üzerinde yapılan çalışmada, öğretmen, ebeveyn ve arkadaş ilişkilerini okul motivasyonu bağlamında incelenmiştir. Araştırmalarda ergenlerin, öğretmen, ebeveyn ve arkadaşlarının desteğini alan bireylerde okula ilişkin ilgi ve hedeflerinin pozitif olarak etkilendiğini ve motivasyon ile akademik başarılarının arasında pozitif yönde ilişki olduğu görülmüştür (Eymur \& Geban, 2011; Wentzel, 1998). Bu durum araştırmanın yapıldı bölgeye göre değişebileceğini, kültürel farklılıkların olabileceğini gösterebilir.

\section{Öneriler}

$\mathrm{Bu}$ çalışmada sadece anket kullanılarak veri toplanmıştır. Nitel yöntem ilerideki çalışmalara eklenebilir.

Çalışmada, erken ergenlik dönemi üzerine yapıldığı için sadece 11-14 yaş grubuna denk gelen ortaokul öğrencilerinden veri toplanmıştır. Alanyazında bu alanda yapılan çalışmaların kısıtlı olduğu görülmüştür. İleride ilkokul ve ortaöğretim öğrencilerinin beden eğitimi ve spor dersine katılmada öğretmen beklentileri ile okul dirençlerinin incelendiği çalışmalar yapılabilir.

Çalışma iç Anadolu bölgesinde yer alan illerde öğrenim gören öğrenciler üzerinde yapılmıştır. Yine farklı bölgeler üzerinde yapılarak bölgesel farklılıklar incelenebilir.

Çıkar Çatışması: Çalışma kapsamında herhangi bir kişisel ve finansal çıkar çatışması bulunmamaktadır.

\section{Etik Kurul İzni ile ilgili Bilgiler}

Kurul Adı: Necmettin Erbakan Üniversitesi Etik Kurulu

Tarih:16/04/2021

Sayı/Karar No: 04/249

\section{KAYNAKLAR}

Ayberk, A., İmamoğlu, O., \& Taşmektepligil, M. Y. (2011). Öğrencilerin beden eğitimi dersi ve ders dışı etkinliklerine yönelik tutumlarının değerlendirilmesi. Spor ve Performans Araştırmaları Dergisi, $2(2), 51-59$. 
Özçelikci E., Erken Ergenlik Döneminde Öğrencilerin Beden Eğitimi ve Spor Dersine Katılmada

Öğretmenden Beklentileri ile Okul Dirençlerinin İncelenmesi.SPORTIVE, 4(2), 77-87

Bağcı, H., \& Temizkan, M. (2006). İlköğretim ikinci kademe öğrencilerinin Türkçe öğretmenlerinden beklentileri. Türk Ĕ̈itim Bilimleri Dergisi, 4(4), 477-498.

Çelikkaleli, Ö. (2015). Ergenlerin cinsiyet, sınıf düzeyi, okul türü ve algılanan ebeveyn tutumlarına göre psikolojik belirtilerinin incelenmesi. Dicle Üniversitesi Ziya Gökalp Eğitim Fakültesi Dergisi, $26,148-162$.

Çelikkaya, T. (2008). İlköğretim ikinci kademe öğrencilerinin sosyal bilgiler öğretmenlerinden beklentileri. Çukurova Üniversitesi Ĕ̈itim Fakültesi Dergisi, 2(40), 38-50.

Ergin, A., \& Karataş, H. (2018). Üniversitese öğrencilerinin başarı odaklı motivasyon düzeyleri. Hacettepe Egitim Dergisi, 33(4), 868-887. https://doi.org/10.16986/HUJE.2018036646

Erkek, A., Uzun, A., \& Emre, M. (2021). Orta ergenlik dönemindeki futbolcularda yaşın, aktif ve pasif sıçramaya etkisi. Sportive, 4(1), 57-68. https://doi.org/10.33459/cbubesbd.948415

Eryılmaz, A. (2013). Okulda motivasyon ve amotivasyon: "derse katılmada öğretmenden beklentiler ölçeği'nin” geliştirilmesi. Mehmet Akif Ersoy Üniversitesi Eğitim Fakültesi Dergisi, 13(15), 1-18.

Eymur, G., \& Geban, Ö. (2011). Kimya öğretmeni adaylarının motivasyon ve akademik başarıları arasındaki ilişkinin İncelenmesi. Egitim ve Bilim, 36(161), 246-255.

Groeneveld, R. A., \& Meeden, G. (1984). Measuring skewness and kurtosis. The Statistician, 33(4), 391. https://doi.org/10.2307/2987742

Kalaycı, H., \& Özdemir, M. (2013). Lise öğrencilerinin okul yaşamının niteliğine ilişkin algılarının okul bağlllıkları üzerine etkisi. GEFA/GUJGEF, 33(2), 293-315. https://doi.org/10.17152/gefd.55136

Kılıç, T., \& Çimen, P. N. (2018). Ortaokul ve lise öğrencilerinin beden eğitimi ve spor dersine karşı tutumlarının incelenmesi. Akdeniz Spor Bilimleri Dergisi, 1(1), 1-13.

Kırbaç, M. (2019). Öğretmenlerin sınıf yönetimi anlayışı ile öğrencilerin okul bağlllığı, okul direnci ve akademik başarısı arasındaki ilişkilerin analizi. İnönü Üniversitesi Eğitim Bilimleri Enstitüsü Eğitim Bilimleri Anabilim Dalı Doktoro Tezi.

Montalvo, G. P. (1997). Pleasing the teacher: an exploration of the construct and its behavioral and motivational patterns. Unpublished Doctoral Dissertation, The University of Oklahoma.

Mouton, S. G., Hawkins, J., McPherson, R. H., \& Copley, J. (1996). School attachment: Perspectives of low-attached high school students. International Journal of Phytoremediation, 16(3), 297-304. https://doi.org/10.1080/0144341960160306

Özbay, Y., Terzi, Ş., Erkan, S., \& Cihangir Çankaya, Z. (2011). Üniversite öğrencilerinin profesyonel yardım arama tutumları, cinsiyet rolleri ve kendini saklama düzeyleri. Pegem Eğitim ve Öğretim Dergisi, 4(1), 59-71. http://www.pegem.net/dosyalar/dokuman/166717serdar.pdf

Özbulat, F. (2020). Ortaokul öğrencilerinin öğrenmeye yönelik sorumluluk düzeylerinin ve okul motivasyonlarının incelenmesi. Sakarya Üniversitesi Eğitim Bilimleri Enstitüsü Eğitim Bİlimleri Anabililm Dalı Yüksek Lisans Tezi.

Phelan, P., Dvidson, A. L., \& Thanh Cao, H. (1992). Speaking up: students' perspectives on school. The Phi Delta Kappan, 73(9), 695-704.

Şişko, M., \& Demirhan, G. (2002). İlköğretim okulları ve liselerde öğrenim gören kız ve erkek öğrencilerin beden eğitimi ve spor dersine ilişkin tutumları. Hacettepe Egitim Dergisi, 23(23), 205210.

Sunay, Y., \& Sunay, H. (1996). Lise öğrencilerïnìn beden eğitimi dersinden beklentileri ve beklentilerïn gerçekleşme düzeyi. Gazi Beden Eğitimi ve Spor Bilimleri Dergisi, 1(4), 35-53. https://dergipark.org.tr/tr/pub/gbesbd/issue/27944/302556

Uzun, A., Akbulut, A., Erkek, A., Pamuk, Ö., \& Bozoğlu, M. S. (2020). International journal of applied exercise physiology. International Journal of Applied Exercise Physiology, 9(8), 168-175. https://doi.org/10.26655/IJAEP.2020.8.1

Vatansever Bayraktar, H. (2015). Sinıf yönetiminde öğrenci motivasyonu ve motivasyonu etkileyen etmenler. International Periodical For The Languages, Literature and History of Turkish or Turkic, 10(3), 1079-1100.

Wentzel, K. R. (1998). Social relationships and motivation in middle school: The role of parents, teachers, and peers. Journal of Educational Psychology, 90(2), 202-209. https://doi.org/10.1037/0022-0663.90.2.202

Yeung, A. S., \& McInerney, D. M. (2005). Students' school motivation and aspiration over high school years. Educational Psychology, 25(5), 537-554. https://doi.org/10.1080/01443410500046804

Yüksel, S. (2003). Öğrencilerin öğrenme-öğretmen sürecine giriş direnç kavramı. Uludă̆ Ünïversitesi Eğitiim Fakültesi Dergïi; 16(1), 235-251. https://dergipark.org.tr/tr/download/article-file/153227 
Özçelikci E., Erken Ergenlik Döneminde Öğrencilerin Beden Eğitimi ve Spor Dersine Katılmada Öğretmenden Beklentileri ile Okul Dirençlerinin İncelenmesi.SPORTIVE, 4(2), 77-87 